\title{
Remarkable multicuspid teeth in a new elusive skate (Chondrichthyes, Rajiformes) from the Mediterranean Pliocene
}

\author{
Alberto Collareta $^{1,2}$ (D) $\cdot$ Frederik H. Mollen $^{3}$ (D) $\cdot$ Marco Merella $^{1} \cdot$ Simone Casati $^{4} \cdot$ Andrea Di Cencio $^{4,5}$ (D)
}

Received: 15 August 2020 / Accepted: 7 December 2020

(c) The Author(s) 2021

\begin{abstract}
Here we report on four highly peculiar skate teeth from Arcille and Certaldo, two Pliocene localities of Tuscany (central Italy). While being attributable to Rajiformes and somewhat reminiscent of Dipturus and Rostroraja, these specimens display an unusual multicuspid tooth design that does not match any extinct or extant skate taxon known to date. The studied teeth are thus referred to a new genus and species of Rajiformes, Nebriimimus wardi gen. et sp. nov., which is here tentatively assigned to the family Rajidae. Based on pronounced morphological similarities between the rather large-sized teeth of the latter and those of extant nurse sharks, we hypothesise that $N$. wardi might have been capable of actively foraging upon relatively large food items compared to other rays. This extinct skate species was likely not a common component of the Pliocene Tuscan marine vertebrate assemblages. The palaeoenvironmental scenarios that $N$. wardi inhabited were marginal-marine and open shelf settings characterised by tropical climate conditions. As $N$. wardi is currently known only from lower to mid-Pliocene deposits of the Mediterranean Basin, it is tempting to speculate that its speciation dates back to an earliest Pliocene phase of diversification that also contributed to the emergence of the Mediterranean endemic stock of extant skate species.
\end{abstract}

Keywords Batomorphii $\cdot$ Elasmobranchii $\cdot$ Pliocene $\cdot$ Italy $\cdot$ Palaeoichthyology $\cdot$ Taxonomy

\section{Introduction}

Handling Editor: Jürgen Kriwet.

Alberto Collareta

alberto.collareta@unipi.it

Frederik H. Mollen

frederik.mollen@gmail.com

Marco Merella

marcomerella1994@gmail.com

Simone Casati

simonecasati@alice.it

Andrea Di Cencio

andreadicencio@geologiaepaleontologia.eu

1 Dipartimento di Scienze Della Terra, Università di Pisa, via S. Maria 53, 56126 Pisa, Italy

2 Museo di Storia Naturale, Università di Pisa, via Roma 79, Calci, 56011 Pisa, Italy

3 Elasmobranch Research, Rehaegenstraat 4, 2820 Bonheiden, Belgium

4 Gruppo Avis Mineralogia e Paleontologia Scandicci, Piazza Vittorio Veneto 1, Badia a Settimo, 50018 Scandicci, Italy

5 Studio Tecnico Geologia e Paleontologia, via Fratelli Rosselli 4, San Casciano Val di Pesa, 50026 Firenze, Italy
Among extant rays (Chondrichthyes: Elasmobranchii: Batomorphii), those assigned to the order Rajiformes (sensu Naylor et al. 2012a) number some 290 species arranged in 38 genera, thus accounting for almost half of the global alphadiversity of rays (Naylor et al. 2012a; Last et al. 2016; Weigmann 2016). Vernacularly known as "skates", these forms generally display a greatly flattened body, a pointed snout, much enlarged pectoral fins, an undulatory pectoral fin motion, pelvic fins that flare laterally and are often divided into two lobes, no caudal sting spines, thorn-like dermal denticles, and a slender tail that is clearly demarcated from the disc (e.g. McEachran and Dunn 1998; Ebert and Compagno 2007; Cappetta 2012; Marramà et al. 2019). Skates are widely distributed in marine waters worldwide and range from nearshore habitats to open-ocean abyssal environments, from the intertidal band down to depths greater than 3000 m (Nelson 1994; Ebert and Compagno 2007; Froese and Pauly 2019). Currently, there is no universal consensus about the family-level classification of skates. On the one hand, based on molecular analyses, Naylor et al. (2012a) and Last et al. (2016) divided the extant members of Rajiformes 
into four families, namely, Anacanthobatidae, Arhynchobatidae, Gurgesiellidae, and Rajidae, the latter being the most diverse one by accounting for more than half of the living species of Rajiformes. On the other hand, the morphological analyses do not unambiguously support the monophyly of all the aforementioned groups, either recognising a single rajiform family (i.e. Rajidae) articulated in several subfamilies and tribes (McEachran and Dunn 1998) or recovering rajids and gurgesiellids as para-/polyphyletic groups (Marramà et al. 2019).

The earliest reliable dental fossils of skates are as old as the Early Jurassic (Stumpf and Kriwet 2019), which matches well the most recent molecular time-divergence estimates (e.g. Bertozzi et al. 2016; Ramírez-Amaro et al. 2018). That said, the fossil record of Rajiformes is scanty to date, and the low number of diagnosable extinct rajiform species contrasts markedly with the high alpha-diversity of the recent stock (Herman et al. 1996). Furthermore, as usual for cartilaginous fishes, the fossil record of rajiforms is mostly constituted by isolated teeth, whose interpretation might often prove difficult (Marramà et al. 2019).

In the present paper, we report on four skate teeth from two Pliocene localities of Tuscany (central Italy). While attributable to Rajiformes, these specimens display an unusual multicuspid tooth design that does not match any extinct or extant skate taxon known to date. The studied teeth are thus here referred to a new genus and species which we tentatively refer to the family Rajidae. An analysis of the relationships of this new taxon and a discussion of its palaeoecological and evolutionary significance are then undertaken on the basis of a detailed characterisation of the idiosyncrasies and affinities of its remarkable tooth morphology.

\section{Materials and methods}

The holotype of the new rajiform taxon described herein is stored in Calci (Pisa Province, Italy), in the palaeontological collection of the Museo di Storia Naturale dell'Università di Pisa (hereinafter: MSNUP) under accession number MSNUP I-16950. The paratype and two referred specimens are stored in Badia a Settimo (Scandicci, Florence Province, Italy), in the permanent exhibition of "Gruppo AVIS Mineralogia e Paleontologia Scandicci" (hereinafter: GAMPS) under accession numbers GAMPS-00926 to GAMPS-00928.

All the specimens were cleaned with deionised water in an ultrasonic bath to remove the sedimentary matrix. Morphological observations were taken using an optical stereomicroscope at Dipartimento di Scienze della Terra dell'Università di Pisa (Pisa, Italy). Measurements were taken using a standard analog caliper. Photographs were taken using a Nikon D5200 digital camera equipped with a macro lens.

Except when explicitly stated otherwise, the dental anatomical terminology utilised in the present paper follows Casier (1947), Herman et al. (1994, 1995, 1996) and Cappetta $(1986,2012)$. In particular, Herman et al. $(1994,1995$, 1996) were the first authors to provide a set of odontological characters for the description of rajiform teeth, which is largely followed here.

The classification of Rajiformes embraced herein follows the schemes proposed by Naylor et al. (2012a) and Last et al. (2016).

\section{Geological and palaeontological setting}

The Mio-Pleistocene successions of Tuscany ("Neoautochtonous" Auctt.; e.g. Pertusati 1981; Bossio et al. 1993, 1994) were deposited in a complex geodynamic setting, characterised by continental collision in the framework of the late orogenic evolution of the Northern Apennines (e.g. DeCelles 2012; Pascucci et al. 2006; Benvenuti et al. 2014). For several centuries, and possibly as long ago as in Renaissance times (Collareta et al. 2020b), the Mio-Pleistocene Tuscan successions have been home to important finds of marine vertebrate remains, which are known internationally since the second half of the XIX century (e.g. Lawley 1876). Among these fossils are remarkable specimens of bony and cartilaginous fishes (sharks, rays and chimaeras), cetaceans (toothed and baleen-bearing whales), sirenians, pinnipeds and sea chelonians, many of which were collected more than one century ago to form conspicuous collections (e.g. Manganelli et al. 2006; Bianucci 2014). The scientific importance of these collections, however, has suffered a setback over the past few decades, following the emergence of modern palaeontological research standards that privilege the study of materials whose geographic and stratigraphic whereabouts are ascertained (Collareta et al. 2020c). That said, recent research efforts have shown that the prospection of new fossiliferous locations can result in a significant update of our knowledge on the marine vertebrates of the Mediterranean Sea during the Pliocene.

Teeth belonging to the new rajiform taxon described herein were collected by the authors from two Tuscan sites where marine Pliocene deposits are exposed, namely, Arcille and Certaldo (Fig. 1). In both these cases, the outcrop areas are located in currently inactive quarries.

The Arcille quarry (Campagnatico, Grosseto Province; GPS geographic coordinates: $42^{\circ} 47^{\prime} 12^{\prime \prime} \mathrm{N}, 11^{\circ} 17^{\prime} 06^{\prime \prime} \mathrm{E}$ ) is located in the Baccinello-Cinigiano Basin of southwestern Tuscany. This basin is filled by Neogene and Quaternary continental and marine deposits that host terrestrial and marine fossil vertebrate assemblages of Miocene and 


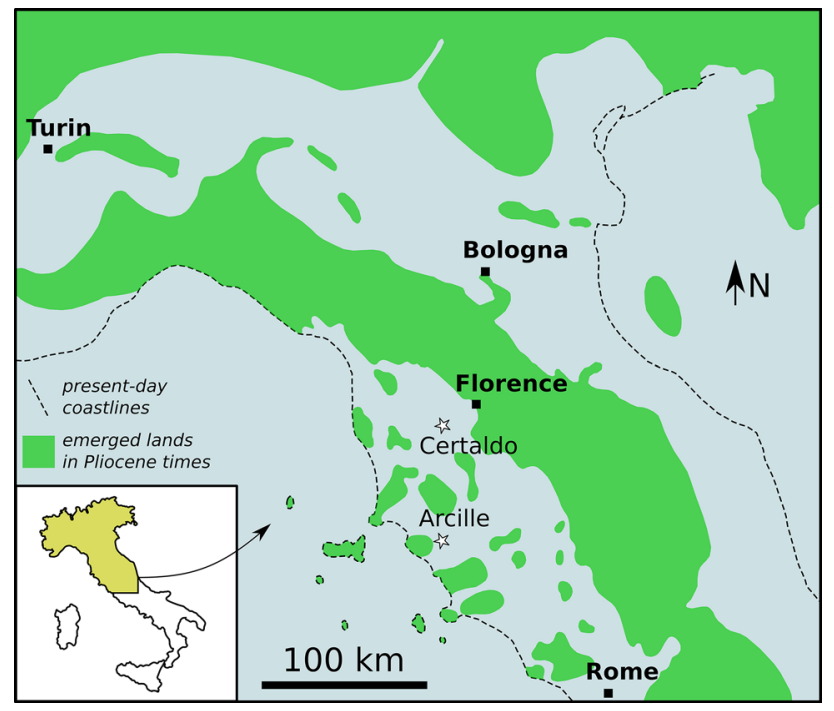

Fig. 1 Schematic palaeogeographic map of central and northern Italy in Pliocene times, showing the location of the sites where the holotype, paratype and referred specimens of the new rajiform taxon described herein were found (Arcille and Certaldo). Paleogeographical reconstruction redrawn and modified after Vai (1989)

Pliocene age (e.g. Benvenuti et al. 2001; Tinelli et al. 2012). The succession exposed at the Arcille quarry consists of marine siliciclastic deposits dominated by yellowish, fossilrich sandstones that alternate with conglomeratic intervals and are topped by greyish shelf mudstones (Tinelli et al. 2012). The fossiliferous sandstones from which the rajiform teeth described herein were collected are representative of deltaic to shoreface, marginal-marine palaeoenvironments (Tinelli 2013). The associated elasmobranch fauna consists of some three hundred teeth and dermal spines and features remains of the families Hexanchidae (Hexanchus griseus), Squatinidae (Squatina sp.), Carcharhinidae (Carcharhinus spp.), Scyliorhinidae (Megascyliorhinus miocaenicus and Pachyscyllium dachiardii), Lamnidae (Cosmopolitodus plicatilis), Carchariidae (Carcharias taurus), Dasyatidae (Dasyatis sp. and Himantura sp.), Myliobatidae (Aetomylaeus bovinus and Myliobatis sp.), Rajidae (Rostroraja olisiponensis) and Rhinobatidae (Rhinobatos sp.) (Bianucci et al. 2019; Merella et al. 2020; Fig. 2). Other vertebrate remains from this deposit include five skeletons of the extinct dugongid sirenian Metaxytherium subapenninum, two skeletons of billfish (Makaira sp.), and the holotype and only known specimen of the archaic monodontid cetacean Casatia thermophila; moreover, teeth of sparid teleosts are very common (Sorbi et al. 2012; Tinelli 2013; Bianucci et al. 2019; Merella et al. 2020). Fossils of macro-invertebrates are abundant in the vertebrate-bearing intervals exposed at Arcille; they are mostly represented by bivalves (mostly pectinids and venerids, including the extinct large-sized clams Callista italica and Pelecyora gigas) but also include gastropods, scaphopods, echinoids, bryozoans, ahermatypic corals (Flabellum? sp.) and acorn barnacles (Bianucci et al. 2019; Merella et al. 2020; AC, MM, SC, and ADC, pers. observ. [2012-2019] on the fossil assemblage of Arcille). According to Sorbi et al. (2012), the fine-grained sediments exposed at Arcille feature a planktic foraminiferal assemblage that has been referred to the lower part of the Zanclean, i.e. the Mediterranean Pliocene (=MPl) zone 2 of Cita (1975), whose bounding bioevents have been calibrated at 5.08 and 4.52 Ma, respectively (Violanti 2012). The Arcille succession can be referred to the "S2 Synthem" recognized in the Neogene sedimentary succession of Tuscany by Dominici et al. (2018). S2 is a large-scale, architecturally complex, and petrographically diverse Zanclean depositional unit that consists of fluvial conglomerates, fluviodeltaic sandstones, and shelfal mudstones (Dominici et al. 2018).

The Certaldo quarry (Florence Province; GPS geographic coordinates: $43^{\circ} 34^{\prime} 08^{\prime \prime} \mathrm{N}, 11^{\circ} 01^{\prime} 51^{\prime \prime} \mathrm{E}$ ) is located in the Valdelsa Basin of central Tuscany. The Valdelsa Basin is filled with some $1000 \mathrm{~m}$ of Mio-Pleistocene sediments (Benvenuti et al. 2014) that are home to rich and diverse fossil vertebrate assemblages comprised of both terrestrial and marine forms (Collareta et al. 2020a, and references therein). The succession exposed at the Certaldo quarry consists of massive, greyish-bluish, shelfal mudstones that crop out along an artificial cliff (Collareta et al. 2020d). Fossils are particularly abundant in a ca. $25-\mathrm{cm}$-thick interval that also feature rare invertebrate burrows. The invertebrate assemblage is comprised of bivalve and gastropod molluscs (mostly venerids and vermetids, including the extinct large-sized clam Pelecyora brocchii and the worm snail Thylacodes arenarius) and a single species of acorn barnacle (Concavus concavus), whereas the vertebrate assemblage consists of a few teeth of elasmobranchs (assigned to Megascyliorhinus miocaenicus, Pachyscyllium distans and Rostroraja olisiponensis) and indeterminate otoliths (Collareta et al. 2020d). The elasmobranch remains, including one of the specimens described herein (i.e. GAMPS-00928), lack a precise stratigraphic position, having been rolled down from the easily erodible artificial cliff to redeposit at its foot. The succession exposed at the Certaldo quarry can be referred to the upper part of the S3 Synthem recognised in the Valdelsa Basin by Benvenuti et al. (2014). $\mathrm{S} 3$ consists of a coarse-grained, deepening-upward, delta front stratal package topped by a fine-grained, open shelf mudstone division (Dominici et al. 2018). According to Benvenuti et al. (2014), the mudstones belonging to the S3 Synthem bear planktonic foraminifer assemblages indicative of the MPl zone 4 of Cita (1975), whose bounding bioevents have been calibrated to 3.98 and $3.19 \mathrm{Ma}$, respectively (Violanti 2012); furthermore, they host calcareous nannofossil assemblages that belong to the 
Fig. 2 Excerpt from the fossil elasmobranch remains associated with the holotype, paratype, and referred specimens of Nebriimimus wardi from the Pliocene localities of Arcille (panels a to $\mathrm{m}$ and o to r) and Certaldo (panel n). a Carcharias taurus; b Isurus oxyrinchus; c Carcharhinus brachyurus; d Myliobatis sp.; e Alopias superciliosus; f Galeocerdo cuvier; g Cosmopolitodus plicatilis; $\mathbf{h}$ Aetomylaeus bovinus; i Carcharhinus cf. falciformis; j Hexanchus griseus; $\mathbf{k}$ Cetorhinus maximus; $\mathbf{l}$ Megascyliorhinus miocaenicus; m Pachyscyllium dachiardii; n Pachyscyllium distans; $\mathbf{0}$ Dasyatis sp.; p Himantura sp.; q Rostroraja olisiponensis; $\mathbf{r}$ Rhinobatos sp. Teeth of Myliobatis sp., Aetomylaeus bovinus, Himantura sp., Dasyatis sp. and Rhinobatos sp. are depicted in apical view; tooth of Rostroraja olisiponensis in labial view; all other teeth in lingual view. Scale bars $=5 \mathrm{~mm}$ except for panel r (1 mm)
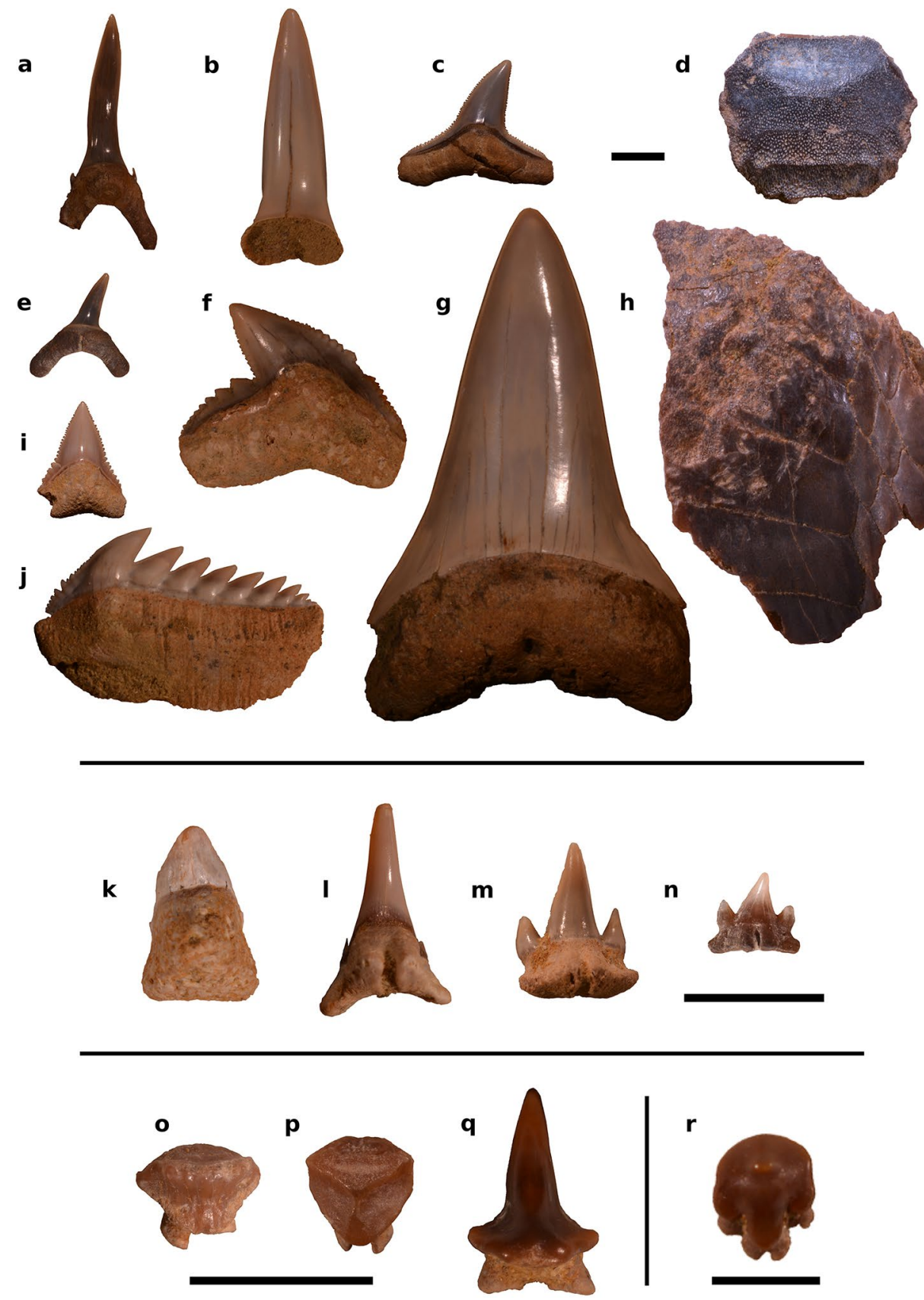

m
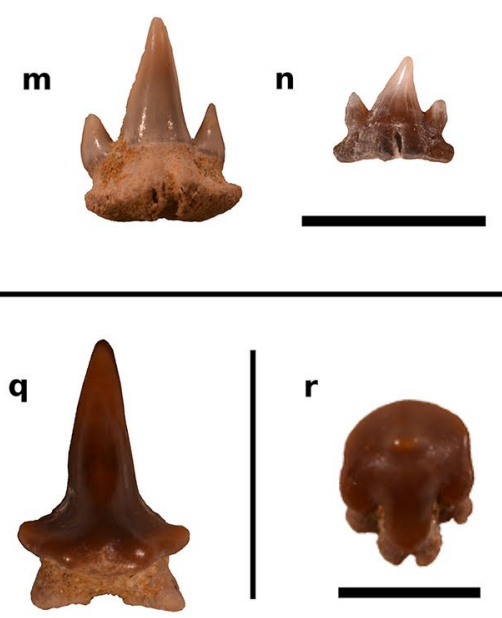

Mediterranean Neogene Nannoplankton (MNN) zone 16a of Rio et al. (1990), which in turn corresponds to the Calcareous Nannofossil Plio-Quaternary (CNPL) zone 4 of the more recent Neogene biozonation of Backman et al. (2012). This zone is defined between the disappearance of Reticulofenestra pseudoumbilicus (occurred at $3.82 \mathrm{Ma}$, as reported by Backman et al. 2012) and the disappearance of Discoaster tamalis (occurred at 2.76 Ma, as reported by Backman et al. 2012). The sediments exposed at the Certaldo quarry can thus be referred to the 3.82-3.19 Ma time span, which is consistent with a late Zanclean or early Piacenzian age.

\section{Systematic palaeontology}

Class Chondrichthyes Huxley, 1880

Subclass Elasmobranchii Bonaparte, 1838

Superorder Batomorphii Cappetta, 1980

Order Rajiformes Berg, 1937

Family ?Rajidae de Blainville, 1816

\section{Genus Nebriimimus nov.}

Derivatio nominis. From the combination of the Latin word "mimus", meaning mimic, with Nebrius, for highlighting 
the morphological similarities between the teeth of the new genus and those of the tawny nurse shark (Nebrius ferrugineus).

Type and only known species. Nebriimimus wardi sp. nov.

Diagnosis. Same as for the type species until other species are described.

Known stratigraphic and geographic range. Pliocene of Italy.

Nebriimimus wardi sp. nov.

Figures 3, 4

Derivatio nominis. The specific name honours David J. Ward, British vertebrate palaeontologist, for his outstanding contribution to the knowledge and understanding of the Neogene elasmobranch fossil record.

Holotype. MSNUP I-16950, a lateroposterior tooth.

Type locality. Arcille quarry, Campagnatico, Grosseto Province, Tuscany, central Italy. GPS geographic coordinates: $42^{\circ} 47^{\prime} 12^{\prime \prime} \mathrm{N}, 11^{\circ} 17^{\prime} 06^{\prime \prime} \mathrm{E}$.

Type horizon. Zanclean marine sandstones belonging to the S2 Synthem of the Tuscan Pliocene. The geological age of the type horizon has been estimated at between 5.08 and $4.52 \mathrm{Ma}$ by means of foraminiferal biostratigraphy (see above for more details).

Paratype. GAMPS-00928, an anterior tooth.

Locality and horizon of the paratype. Pliocene (3.82$3.19 \mathrm{Ma}$ ) open shelf mudstones exposed at Certaldo,
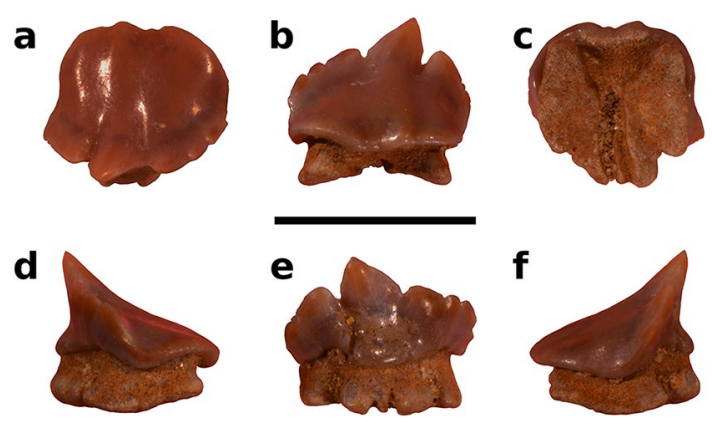

Fig. 3 Nebriimimus wardi gen. et sp. nov., MSNUP I-16950 (holotype), lateroposterior tooth from the lower Pliocene (Zanclean) of Arcille (Campagnatico, Grosseto Province, Tuscany, central Italy) in a apical; b labial; c basal; $\mathbf{d}$ mesial; e lingual; and $\mathbf{f}$ distal views. Scale bar $=5 \mathrm{~mm}$
Florence Province, Tuscany, central Italy. GPS geographic coordinates: $43^{\circ} 34^{\prime} 08^{\prime \prime} \mathrm{N}, 11^{\circ} 01^{\prime} 51^{\prime \prime} \mathrm{E}$.

Other referred specimens. GAMPS-00926, an anterior tooth, and GAMPS-00927, an anterior or anterolateral tooth. Both GAMPS-00926 and GAMPS-00927 come from the type locality and horizon.

Diagnosis. A rajiform skate known from four teeth displaying the following unique combination of characters: teeth relatively large-sized, reaching $5.5 \mathrm{~mm}$ in maximum mesiodistal width; crown relatively low, comprised of a smooth enameloid surface, in which a single transverse keel develops a complete, multicuspid cutting edge; mesial and distal margins of transverse keel sharp, concavely arched, reaching the crown base; up to three, well-distinct, blunt to moderately pointed cusplets present on each side of the more prominent, robust, central main cusp; cusplets decreasing in size towards the crown base and converging towards or parallel to the central main cusp, never diverging radially; labial crown face well-developed, very oblique and concavoconvex in profile, with one to three irregular labiolingual ridges, forming parallel depressions in-between; second transverse keel (i.e. labial cutting edge) not present; basal margin of the crown strongly convex and undulate, following the labiolingual ridges and depressions, often displaying a central indentation for tooth interlocking; central ridge forming a prominent bulge ornamenting the apron; apron broad, basally inclined, not reaching the root base; lingual crown face reduced, abrupt, incised by two subvertical grooves that represent prolongations of the main cusp edges and project at the sides of the central uvula; central uvula present, welldistinct, low, rounded, supported by a large medial protuberance of the inner root part; prominent lateral uvulae absent, but a pair of lateral, much smaller protuberances of the inner root often present; crown slightly broader than the root; crown-root junction incised, with no root coating; root roughly cordiform, low, robust, not displaced lingually; root base almost flat; vascularisation pattern holaulacorhize, with a deep central nutrient groove dividing the root in two lobes; nutrient groove expanding anteriorly in its anterior half, displaying several nutrient foramina of variable size and shape in its median region; additional foramina often present at the sides of the root; root lobes similar in size to each other, only weakly flaring distally, contributing equally to form the central lingual root protuberance; monognathic heterodonty present, anterior teeth symmetrical, lateroposterior teeth asymmetrical, having the main cusp deflected towards the commissure and poorly individualised lateral cusplets.

Description. The holotype MSNUP I-16950 (Fig. 3) is a $4.5-\mathrm{mm}$-wide, clearly asymmetrical tooth. In light of its asymmetry, MSNUP I-16950 is here regarded as 

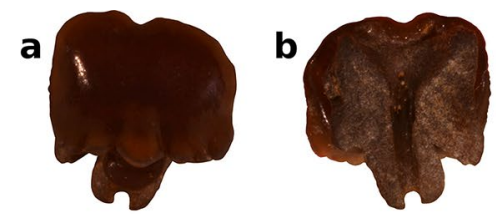

$\mathbf{f}$

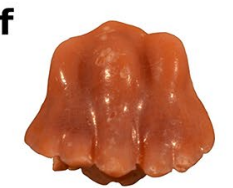

g
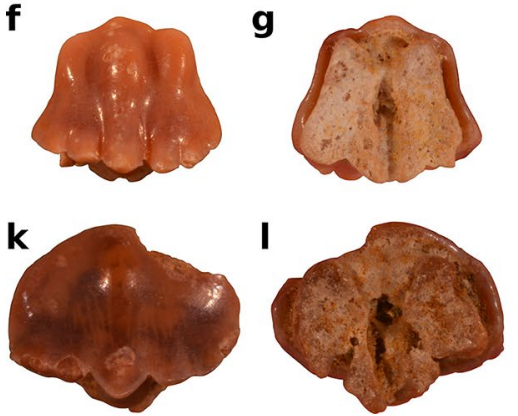

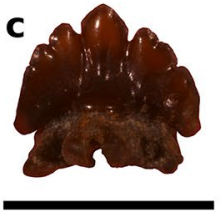

h
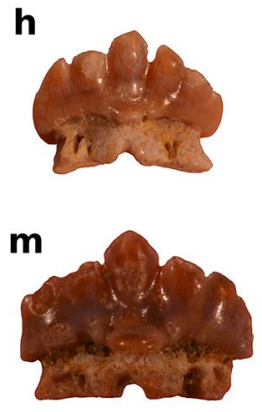
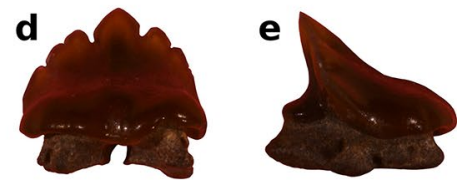

i

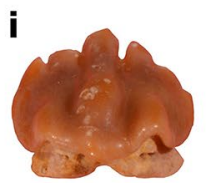

j
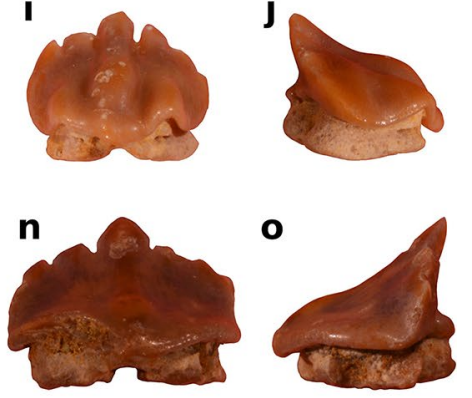

Fig. 4 Nebrimimus wardi gen. et sp. nov., paratype and referred specimens. a-e GAMPS-00928 (paratype), anterior tooth from the Pliocene of Certaldo (Florence Province, Tuscany, central Italy), in a apical; b basal; c lingual; d labial; and e profile views. f-j GAMPS00926 (referred specimen), anterior tooth from the lower Pliocene
(Zanclean) of Arcille (Campagnatico, Grosseto Province, Tuscany, central Italy) in $\mathbf{f}$ apical; $\mathbf{g}$ basal; $\mathbf{h}$ lingual; $\mathbf{i}$ labial; and $\mathbf{j}$ profile views. k-o GAMPS-00927 (referred specimen), anterior or anterolateral tooth from the lower Pliocene (Zanclean) of Arcille in $\mathbf{k}$ apical; $\mathbf{l}$ basal; $\mathbf{m}$ lingual; $\mathbf{n}$ labial; and $\mathbf{o}$ profile views. Scale bar $=5 \mathrm{~mm}$ representative of a lateral or posterior position (see also Herman et al. 1994, 1995, 1996). The central main cusp is prominent and pointed, slightly displaced laterally and deflected towards the commissure (Fig. 3a, b). Three cusplets are observed along the mesial margin of the transverse keel, pointing towards the central main cusp. A single wellindividualised lateral cusplet is placed adjacent to the central main cusp, also pointing towards the central main cusp (Fig. 3b, e). Two much smaller lateral cusplets are observed, in form of low and rounded crenulations of the distal margin of the transverse keel. A single irregular, labiolingual ridge is observed, broad and low, on the labial face of the crown, running from the central main cusp to the anterior basal margin of the crown (Fig. 3a). A broad apron is present (Fig. 3d, f), showing a central indentation for tooth interlocking (Fig. 3b). The root displays mesiodistally expanded lobes. The latter are divided from each other by a labiolingual furrow that significantly expands anteriorly in its labial half (Fig. 3c). The lingual half of the nutritive furrow is bisected by a low longitudinal ridge, as sometimes observed in teeth of extant Dipturus (e.g. Herman et al. 1995: pl. 18).

The paratype GAMPS-00928 (Fig. 4a-e) is a 4.5-mmwide, mostly symmetrical tooth. In light of its overall symmetric morphology, it is here interpreted as representative of an anterior position (see also Herman et al. 1994, 1995, 1996); as a consequence of this, the mesial and distal cutting edges could not be unambiguously identified. The central main cusp is flanked on each side by three cusplets (Fig. 4a, $\mathrm{c}, \mathrm{d})$. The central main cusp and the adjoining cusplets are parallel to each other. Otherwise, the aspect of the labial crown face recalls that of the holotype. The root is also strongly reminiscent of the holotype, but it displays slightly more prominent lingual protuberances at the sides of the central uvula (Fig. 4a, b, e).

The referred specimen GAMPS-00926 (Fig. 4f-j) is also a 4.5-mm-wide, largely symmetrical tooth; as such, it is here interpreted as representative of an anterior position. Two and three cusplets are present at the sides of the central main cusp (Fig. 4f, h, i). Three prominent, irregular labiolingual ridges are observed on the labial face of the crown, proceeding from the central cusp and contiguous cusplets (Fig. 4f, i, j). The central ridge is the broadest and the most salient one and terminates in a rounded apron with no traces of indentation for tooth interlocking (Fig. 4f, g, i, j). As regards the root, the nutrient furrow expands anteriorly in a less prominent way than observed in either the holotype or the paratype (Fig. 4g). The root projection supporting the central uvula is not much lingually extended, and it is only moderately larger than the adjoining lateral root protuberances.

The referred specimen GAMPS-00927 (Fig. 4k-o) is a 5.5-mm-wide, substantially symmetrical tooth, here interpreted as representative of an anterior or anterolateral position. The crown is locally damaged. The central main cusp is rather prominent compared to the cusplets, thus recalling the condition seen in the holotype (Fig. 4m, n). As in the referred specimen GAMPS-00926, two and three cusplets are present at the sides of the central main cusp (Fig. 4k, m, $\mathrm{n})$. As in the paratype, the cusplets are parallel to each other as well as to the central main cusp. The labial crown face is significantly wider than labiolingually high, and it displays 
a single labiolingual ridge (Fig. 4k). The latter is very low in its apicolingual half and becomes more prominent anteriorly to form a bulging, circular pustule that ornaments the partly preserved apron (Fig. 4k, n, o). The basal margin of the crown is locally damaged but, judging from the preserved parts, a central indentation for tooth interlocking was likely not present (Fig. 4k, 1). The root is also moderately damaged; however, in basal view, its outline appears as somewhat intermediate between that of the referred specimen GAMPS00926 and those of the holotype and paratype (Fig. 41).

Notes on heterodonty. Monognathic heterodonty is evident in Nebriimimus wardi as the holotype has its main cusp deflected towards the commissure and poorly individualised lateral cusplets (Fig. 3a, b, e), whereas the paratype and referred specimens are largely symmetrical teeth bisected by the central main cusp (Fig. 4a, c, d, f, h, i, k, m, n). In light of the patterns of monognathic heterodonty of extant skates (e.g. Herman et al. 1994, 1995, 1996), the holotype is here regarded as a lateroposterior tooth, the other specimens being consistent with anterior or anterolateral (in case of GAMPS-00927) positions. Dignathic and gynandric heterodonty are difficult to define due to the low number of specimens.

Comparisons and remarks. The teeth of Nebriimimus wardi display relatively large dimensions, their size recalling that of the teeth of the extant rajids Dipturus and Rostroraja. The root design of Nebriimimus wardi and the morphology of its apron (which often features an indentation for tooth interlocking) also recall Dipturus and Rostroraja, and especially the extant Rostroraja alba and the extinct Rostroraja olisiponensis (e.g. Cappetta and Nolf 1991: pl. 4, fig. 1; Herman et al. 1995: pls. 42-46; Cappetta 2012: fig. 348), the latter being also known under the generic names Dipturus and Raja (Cappetta and Cavallo 2006; Fialho et al. 2019). In these aspects, the teeth of $N$. wardi resemble also one of the two Tuscan Pliocene teeth figured by Lawley (1876: pl. 2, fig. 2) as belonging to Raja suboxyrhynchus (see also Cappetta 2006 and Cappetta and Cavallo 2006). Raja suboxyrhynchus might be a senior synonym of Narcine (=Dipturus) olisiponensis, the latter having been instituted almost a century later by Jonet (1968). However, replacing the widely used name $R$. olisiponensis (Jonet 1968) with Rostroraja suboxyrhynchus (Lawley 1876) is not in the interest of nomenclatural stability; therefore, considering that conditions could exist allowing for the reversal of precedence (Article 23.9.1 of the International Code of Zoological Nomenclature; ICZN 1999), the latter might be regarded as a nomen oblitum and consequently abandoned in favour of the former (the nomen protectum), that is in case a synonymy between $R$. olisiponensis and $R$. suboxyrhynchus would be established.
As regards the crown morphology, the sharp, concavely arched, complete transverse keel of $N$. wardi is somewhat reminiscent of the condition observed in females of Rostroraja olisiponensis (e.g. Cappetta 2012: fig. 348, panels F-H), as well as in females of the so-called "Dipturus batis complex" (e.g. Herman et al. 1995: pl. 18; Iglésias et al. 2010). These females might also display some kind of low and blunt cusplet-like eminences at both sides of the central main cusp (Cappetta 2012; FHM, pers. obs.). That said, the obviously multicuspid crown of $N$. wardi has no analogue in any Cenozoic member of Rajiformes, either extant or extinct. Stronger resemblances can in turn be highlighted with the mid-Cretaceous species Engolismaia couillardi, a rajiform incertae familiae (Vullo et al. 2007). In the latter form, the transverse keel develops one to two distinct and blunt pairs of cusplets, slightly lower than the main cusp, and a rather prominent mediolabial protuberance provided with a single pustule is also present (Vullo et al. 2007). However, E. couillardi differs from $N$. wardi by displaying a distinctly smaller size (the teeth of E. couillardi are not wider than $1 \mathrm{~mm}$ ), more robust and slightly diverging cusplets, and a greatly different morphology of the lingually displaced root (e.g. Vullo et al. 2007: fig. 7; Cappetta 2012: fig. 391).

For summarising, the dental design of the new taxon described herein does not match any extinct or extant rajiform taxon known to date, but affinities with the rajids Rostroraja and Dipturus as well as with the rajiform incertae familiae Engolismaia can be pointed out.

\section{Discussion}

\section{Remarks on the order- and family-level attribution}

Nebriimimus wardi is assigned to the skate order Rajiformes by virtue of the following combination of characters: tooth size subcentimetric; crown cuspidate, robust, mesiodistally broad, provided with a distinct transverse cutting edge as well as with features for tooth interlocking; root stout, holaulacorhize, bilobate, weakly flaring basally (see also Herman et al. 1994, 1995, 1996; Cappetta 2012; Stumpf and Kriwet 2019).

As anticipated above, according to molecular analyses, extant Rajiformes are represented by four families, i.e. Anacanthobatidae, Arhynchobatidae, Gurgesiellidae and Rajidae (Last et al. 2016; Weigmann 2016). Before the recent elevation of the subfamilies Anacanthobatinae, Arhynchobatinae, and Gurgesiellinae to the family-level, Rajidae was regarded as the sole skate family; as a consequence of this, the majority of the Cenozoic rajiforms that are currently known from the fossil record have been referred to Rajidae (e.g. Cappetta 2006, 2012). Fossil teeth of Anacanthobatidae and Arhynchobatidae have not been reported to date, whereas two skate 
species that were recently described from the Ypresian-Lutetian (Eocene) of southwestern France (Adnet 2006) have been assigned to "Malacoraja-Cruriraja" (i.e. RajidaeGurgesiellidae), so that their higher taxonomic assignment is as yet undecided (see also Cappetta 2012).

It must be noted, however, that the dental characters of Rajiformes are of limited utility for detecting the precise familial position of isolated teeth (Marramà et al. 2019). Herman et al. (1996) were the first to list odontological characters for Rajiformes, but they did not provide a dental key to separate the aforementioned families. On the contrary, the phylogenetic tree presented by Herman et al. (1996: text-fig. 12) does not reflect relationships that are generally accepted to date and that are based on other morphological and molecular pieces of evidence (see e.g. Naylor et al. 2012a, b). However, the species descriptions by Herman et al. $(1994,1995,1996)$ provide a lot of valuable information, such as the absence of uvula and apron in at least the type genera of the families Anacanthobatidae, Arhynchobatidae and Gurgesiellidae, whereas these structures are often present in Rajidae. Because both uvula and apron are present in the material described in the present study, herein we tentatively assign $N$. wardi to the family Rajidae. That said, as for other rajiform taxa that are known only by teeth whose morphological traits do not match any living skate taxon, the family-level attribution of $N$. wardi must be regarded as preliminary and provisional until articulated specimens are discovered.

\section{Functional morphology}

The living members of Rajiformes exhibit clutching- or crushing-type dentitions (sensu Cappetta 2012). In species that display a relevant degree of gynandric heterodonty, males are usually characterised by high-crowned teeth that comprise a clutching-type dentition, whereas females have mostly low-crowned teeth that comprise a crushingtype dentition (Cappetta 1986, 2012). Although the causes beneath the emergence of such a gynandric heterodonty are still far from being understood, gynandric heterodonty has been proposed to diminish a too strong intraspecific competition for food resources (Feduccia and Slaughter 1974). More recent research efforts (e.g. McCourt and Kerstitch 1980; Kajiura and Tricas 1996; Gutteridge and Bennett 2014; de Sousa Rangel et al. 2014, 2016) have shown that the emerge and persistence of gynandric heterodonty in batoids is most likely related to the copulation/breeding success. That said, species displaying clutching- and crushing-type dentitions are clearly linked to different trophic styles and target preys (Cappetta 1986, 2012, and references therein). As highlighted above, the tooth design of Nebriimimus wardi, as known by the four teeth described herein, differs from that of all other rajid skates by the presence of up to three lateral cusplets at both sides of the central main cusp (although, as already mentioned, a kind of low and blunt cusplet can be observed occasionally at each side of the central main cusp in some teeth of extant Dipturus). On the other hand, the multi-cuspid crown of the teeth of $N$. wardi is strongly reminiscent of the tooth design of modern nurse sharks (Orectolobiformes: Ginglymostomatidae: Ginglymostoma and Nebrius), in which the obliquely oriented cutting edge bears strong serrations, and the salient and wide apron largely overhangs the labial face of the root (e.g. Herman et al. 1992; Cappetta 2012). As regards the feeding habits of extant ginglymostomatids, Ginglymostoma cirratum has been shown to be capable of foraging in a peculiar mode, the so-called "spit-suck manipulation", which consists of several repeated spit and suction behaviours and appears to allow nurse sharks to feed upon comparatively large food items (Matott et al. 2005). Although the role of dentition in the mostly suction-based feeding style of nurse sharks is still unclear, the teeth might come into action when dealing with very large food items (e.g. twice the gape-size) for holding the prey in-between two sucking attempts. According to Motta et al. (2002) and Matott et al. (2005), spit-suck manipulation in nurse sharks seems to commonly result in dismembering large food items, and the teeth likely have a role in that - at least by granting food dismembering after various passages of the prey from inside the mouth outwards. On the other hand, the multicuspid teeth of the tawny nurse shark Nebrius ferrugineus allow for scavenging on whale carrion (Lea et al. 2019), whose dismembering requires an active, cutting role of dentition. As long as suggested by the analogy with the nurse shark dentition, the peculiar dental design of $N$. wardi might have favoured this extinct species in feeding upon relatively large food items compared to other rays, with a somewhat active role of the teeth. The denticulate, comb-like cutting edges of the teeth of $N$. wardi might indeed have been able to provide some ability to dismember soft prey items.

\section{Palaeoecological inferences}

During deposition of the sediments from which teeth of $N$. wardi are known, the Mediterranean Sea was warmer than today, with tropical to subtropical climatic conditions (e.g. Raffi and Monegatti 1993; Monegatti and Raffi 2001; Prista et al. 2015; Ragaini et al. 2019). This is also suggested by the recent discovery of rostral spines of the Indo-Pacific knifetooth sawfish Anoxypristis from open shelf mudstones, belonging to the same $\mathrm{S} 3$ synthem exposed at Certaldo, cropping out at the nearby locality of Tegoliccio (Florence Province, Tuscany) (Collareta et al. 2017a). Some further insights on the palaeoenvironmental preferences of $N$. wardi come from the taxonomic composition of the fish assemblage from the type locality, i.e. Arcille (Bianucci et al. 2019) (Fig. 2). 
At this site, the presence of the bull shark (Carcharhinus leucas) and bull ray (Aetomylaeus bovinus) suggests a shallowmarine palaeoenvironment, close to a river mouth, whereas the bluntnose sixgill shark (Hexanchus griseus), the bigeye thresher shark (Alopias superciliosus) and marlin (Makaira sp.) indicate strong connections with open-sea, deep-water habitats (Merella et al. 2020). Furthermore, the presence of the bull shark, which currently inhabits the coasts of Western Africa but not the Mediterranean Sea, suggests truly tropical palaeoclimatic conditions (Merella et al. 2020). Supporting this interpretation, the elasmobranch assemblage described herein takes its place besides remains of marine invertebrates and vertebrates that are typical of shallow and warm waters, such as Metaxytherium subapenninum, a tropical and coastal-estuarine form which likely shared the environmental preferences of modern sirenians (Sorbi et al. 2012). The palaeoenvironmental scenario evoked by the mudstone succession exposed at Certaldo differs from that of Arcille by its relatively deeper, offshore setting, as also suggested by the scanty elasmobranch assemblage (Collareta et al. 2020d). Faunal elements shared between Arcille and Certaldo include Rostroraja olisiponensis, which is thought to be ancestral to the extant white ray Rostroraja alba (Bor et al. 2012); the latter currently inhabits the shelfal environments of the Mediterranean Sea between about 40 and $400 \mathrm{~m}$ depth (Serena 2005). Although precise palaeobathymetric estimates are not available for the strata from which teeth of $N$. wardi are known, this extinct skate species might have inhabited a relatively broad range of water depths, similar to its living relative $R$. alba. The fact that, in spite of more than two centuries of research on the fossil elasmobranchs of Tuscany (Manganelli and Spadini 2003), only a few specimens of $N$. wardi have been discovered so far suggests that this skate species was not a common component of the Pliocene Tuscan marine vertebrate assemblages.

\section{Implications for the evolutionary history of Mediterranean skates}

While representing less than $1 \%$ of the global ocean surface, the Mediterranean Sea is characterised by a rather high cartilaginous fish biodiversity (Quignard and Tomasini 2000), with about $8 \%$ of all the extant elasmobranch species being present in this basin (Serena 2005). More specifically, the modern Mediterranean assemblage of rajid skates is comparatively conspicuous, being indeed comprised of sixteen nominal species, five of which are even endemic to the Mediterranean Sea (Notarbartolo di Sciara and Bianchi 1998; Froese and Pauly 2019; Valsecchi et al. 2005; Serena et al. 2010). As a consequence of this, the evolutionary history of the Mediterranean rajiforms has recently been the target of devoted research efforts (e.g. Valsecchi et al. 2005;
Ramírez-Amaro et al. 2018) that have led to hypothesise that the Mediterranean skates underwent a relatively recent diversification phase, occurring between the middle Miocene and the early Pleistocene. In particular, the emergence of at least some of the Mediterranean endemic species of Rajidae seems to have occurred after the Messinian Salinity Crisis that impacted the Mediterranean biota around 5.97-5.33 Ma (Manzi et al. 2013). As Nebriimimus wardi is currently known only from lower to mid-Pliocene deposits of the Mediterranean Basin, it is tempting to speculate that its speciation dates to the aftermath of the Messinian Salinity Crisis. The disappearance of $N$. wardi might in turn have occurred during the late Pliocene, in the frame of an extinction event that significantly affected the elasmobranchs as well as several other members of the marine megafauna following an abrupt loss of productive coastal habitats (Pimiento et al. 2017). Interestingly, at about the same time, several warm-water marine vertebrates and macro-invertebrates disappeared from the Mediterranean Sea, hinting at a significant episode of climate degradation of the Mediterranean waters that accompanied the onset of the long-term Northern Hemisphere glaciation (Raffi and Monegatti 1993; Monegatti and Raffi 2001; Sorbi et al. 2012; Collareta et al. $2017 \mathrm{a}, \mathrm{b})$. Therefore, if $N$. wardi was indeed a thermophilic skate species, then its extinction could reflect a severe cooling phase around $3 \mathrm{Ma}$. That said, a better understanding of the palaeobiogeographic and chronostratigraphic range of $N$. wardi is definitively needed for confirming or disproving these tantalising conjectures.

Acknowledgements Our gratitude to David J.. Ward, for sharing his much precious expertise on the dentition of extant and extinct elasmobranchs during the earliest phases of this research. Dirk Hovestadt, Walter Landini, Giovanni Bianucci and Franco Cigala Fulgosi are also kindly acknowledged for fruitful discussion on the issues dealt with herein. Thanks are due to Chiara Sorbini and Simone Farina for granting access to the fossil and recent specimens under their care. Not least, Giuseppe Marramà, Jaime Villafaña, Assoc. editor Jürgen Kriwet and Editor-in-chief Mike Reich are kindly acknowledged for their constructive criticisms that greatly contributed to improve an early draft of the present paper.

Funding Open access funding provided by Università di Pisa within the CRUI-CARE Agreement.

Open Access This article is licensed under a Creative Commons Attribution 4.0 International License, which permits use, sharing, adaptation, distribution and reproduction in any medium or format, as long as you give appropriate credit to the original author(s) and the source, provide a link to the Creative Commons licence, and indicate if changes were made. The images or other third party material in this article are included in the article's Creative Commons licence, unless indicated otherwise in a credit line to the material. If material is not included in the article's Creative Commons licence and your intended use is not permitted by statutory regulation or exceeds the permitted use, you will need to obtain permission directly from the copyright holder. To view a copy of this licence, visit http://creativecommons .org/licenses/by/4.0/. 


\section{References}

Adnet, S. 2006. Nouvelles faunes de Sélaciens (Elasmobranchii, Neoselachii) de l'Eocène moyen des Landes (Sud-Ouest, France). Implication dans la connaissance des communautés de sélaciens d'eaux profondes. PalaeoIchthyologica 10: 1-128.

Backman, J., I. Raffi, D. Rio, E. Fornaciari, and H. Pälike. 2012. Biozonation and biochronology of Miocene through Pleistocene calcareous nannofossils from low and middle latitudes. Newsletters on Stratigraphy 45(3): 221-244.

Benvenuti, M., M. Papini, and L. Rook. 2001. Mammal Biochronology, UBSU and paleoenvironment evolution in a post-collisional basin: evidence from the Late Miocene Baccinello-Cinigiano Basin in southern Tuscany, Italy. Bollettino della Società Geologica Italiana 120: 97-118.

Benvenuti, M., S. Del Conte, N. Scarselli, and S. Dominici. 2014. Hinterland basin development and infilling through tectonic and eustatic processes: latest Messinian-Gelasian Valdelsa Basin, Northern Apennines, Italy. Basin Research 26: 387-402. https:// doi.org/10.1111/bre.12031.

Berg, L.S. 1937. A classification of fish-like vertebrates. Bulletin de l'Académie des Sciences de l'URSS 4: 1277-1280.

Bertozzi, T., M.S.Y. Lee, and S.C. Donnellan. 2016. Stingray diversification across the end-Cretaceous extinctions. Memoirs of Museum Victoria 74: 379-390. https://doi.org/10.24199/j.mmv.2016.74.26.

Bianucci, G. 2014. I cetacei fossili nei musei italiani. Museologia Scientifica Memorie 13: 7-17.

Bianucci, G., F. Pesci, A. Collareta, and C. Tinelli. 2019. A new Monodontidae (Cetacea, Delphinoidea) from the lower Pliocene of Italy supports a warm-water origin for narwhals and white whales. Journal of Vertebrate Paleontology 39(3): e1645148. https://doi. org/10.1080/02724634.2019.1645148.

de Blainville, H.M. 1816. Prodrome d'une nouvelle distribution systématique du règne animal. Bulletin des Sciences par la Société Philomathique de Paris 8(105-112): 121-124.

Bonaparte, C.L. 1838. Selachorum tabula analytica. Nuovi Annali delle Scienze Naturali 1(2): 195-214.

Bor, T., T. Reinecke, and S. Verschueren. 2012. Miocene Chondrichthyes from Winterswijk-Miste, The Netherlands. Palaeontos 21: $1-136$.

Bossio, A., A. Costantini, L.M. Foresi, R. Mazzanti, R. Mazzei, B. Monteforti, G.F. Salvatorini, F. Sandrelli, and G. Testa. 1994. Note preliminari sul neoautoctono della Sassa (settore sud-ovest del Bacino di Volterra, province di Pisa e Livorno). Studi Geologici Camerti 1: 33-44.

Bossio, A., A. Costantini, A. Lazzarotto, D. Liotta, and R. Mazzanti. 1993. Rassegna delle conoscenze sulla stratigrafia del Neoautoctono toscano. Memorie della Società Geologica Italiana 49: 17-98.

Cappetta, H. 1980. Les sélaciens du Crétacé supérieur du Liban. II: Batoïdes. Palaeontographica (A: Paläozoologie, Stratigraphie) 168(5-6): 149-229.

Cappetta, H. 1986. Types dentaires adaptatifs chez les sélaciens actuels et post-paléozoïques. Palaeovertebrata 16(2): 57-76.

Cappetta, H. 2006. Elasmobranchii Post-Triadici (Index specierum et generum). In Fossilium Catalogus I: Animalia, 142, ed. W. Riegraf, 1-472. Leiden: Backhuys.

Cappetta, H. 2012. Chondrichthyes. Mesozoic and Cenozoic Elasmobranchii: Teeth. In Handbook of Paleoichthyology, 3E, ed. H.-P. Schultze, 1-512. Munich: F. Pfeil.

Cappetta, H., and D. Nolf. 1991. Les sélaciens du Pliocène inférieur de Le Puget-sur-Argens (Sud-Est de la France). Palaeontographica Abteilung A, Paläozoologie-Stratigraphie 218(1-3): 49-67.

Cappetta, H., and O. Cavallo. 2006. Les Sélaciens du Pliocène de la région d'Alba (Piémont, Italie Nord-Ouest). Rivista Piemontese di Storia Naturale 27: 33-76.
Casier, E. 1947. Constitution et évolution de la racine dentaire des Euselachii. I. - Note préliminaire. Bulletin du Musée royal d'Histoire naturelle de Belgique 23: 1-15.

Cita, M.B. 1975. Studi sul Pliocene e gli strati di passaggio dal Miocene al Pliocene. VII. Planktonic foraminiferal biozonation of the Mediterranean Pliocene deep-sea record. A revision. Rivista Italiana di Paleontologia e Stratigrafia 81: 527-544.

Collareta, A., S. Casati, R. Catanzariti, and A. Di Cencio. 2017a. First record of the knifetooth sawfish Anoxypristis (Elasmobranchii: Rhinopristiformes) from the Pliocene of Tuscany (central Italy). Neues Jahrbuch für Geologie und Paläontologie, Abhandlungen 284(3): 289-297. https://doi.org/10.1127/njgpa/2017/0663.

Collareta, A., S. Casati, and A. Di Cencio. 2017b. A pristid sawfish from the lower Pliocene of Lucciolabella (Radicofani basin, Tuscany, central Italy). Atti della Società Toscana di Scienze Naturali, Memorie Serie A 124: 49-55. https://doi.org/10.2424/ASTSN .M.2017.18.

Collareta, A., S. Casati, M.A.L. Zuffi, and A. Di Cencio. 2020a. First authentic record of the freshwater turtle Mauremys from the upper Pliocene of Italy, with a new occurrence of the rarely reported ichnotaxon Thatchtelithichnus holmani. Carnets de Geologie. https ://doi.org/10.2110/carnets.2020.2016.

Collareta, A., M. Collareta, A. Berta, and G. Bianucci. 2020b. On Leonardo and a fossil whale: a reappraisal with implications for the early history of palaeontology. Historical Biology. https://doi. org/10.1080/08912963.2020.1787403.

Collareta, A., M. Merella, S. Casati, and A. Di Cencio. 2020c. Did titanic stingrays wander the Pliocene Mediterranean Sea? Some notes on a giant-sized myliobatoid stinger from the Piacenzian of Italy. Neues Jahrbuch für Geologie und Paläontologie, Abhandlungen 298(2): 166-164. https://doi.org/10.1127/njgpa /2020/0941.

Collareta, A., M. Merella, F.H. Mollen, S. Casati, and A. Di Cencio. 2020d. The extinct catshark Pachyscyllium distans (Probst, 1879) (Elasmobranchii: Carcharhiniformes) in the Pliocene of the Mediterranean Sea. Neues Jahrbuch für Geologie und Paläontologie, Abhandlungen 295(2): 129-139. https://doi.org/10.1127/njgpa /2020/0877.

DeCelles, P.G. 2012. Foreland basin systems revisited: variations in response to tectonic settings. In Tectonics of Sedimentary Basins: Recent Advances, eds. C. Busy, and A. Azor, 405-426. New York: Wiley. https://doi.org/10.1002/9781444347166.ch20.

Dominici, S., S. Danise, and M. Benvenuti. 2018. Pliocene stratigraphic paleobiology in Tuscany and the fossil record of marine megafauna. Earth-Science Reviews 176: 277-310. https://doi. org/10.1016/j.earscirev.2017.09.018.

Ebert, D.A., and L. J. V. Compagno. 2007. Biodiversity and systematics of skates (Chondrichthyes: Rajiformes: Rajoidei). In Biology of skates, eds. D.A. Ebert, and J.A. Sulikowski. Environmental Biology of Fishes 80(2-3): 111-124. https://doi. org/10.1007/978-1-4020-9703-4_2.

Feduccia, A., and B.H. Slaughter. 1974. Sexual dimorphism in skates (Rajidae) and its possible role in differential niche utilization. Evolution 28(1): 164-168. https://doi.org/10.2307/2407249.

Fialho, P., A. Balbino, and M.T. Antunes. 2019. Langhian rays (Chondrichthyes, Batomorphii) from Brielas, Lower Tagus Basin, Portugal. Geologica Acta 17(7): 1-16. https://doi.org/10.1344/Geolo gicaActa2019.17.7.

Froese, R., and D. Pauly, eds. 2019. FishBase (version 12/2019). Available from: www.fishbase.org, accessed on July 30, 2020.

Gutteridge, A.N., and M.B. Bennett. 2014. Functional implications of ontogenetically and sexually dimorphic dentition in the eastern shovelnose ray, Aptychotrema rostrata. Journal of Experimental Biology 217: 192-200. https://doi.org/10.1242/jeb.089326.

Herman, J., M. Hovestadt-Euler, and D.C. Hovestadt. 1992. Part A: Selachii. No. 4: Order Orectolobiformes - Families: 
Brachaeluridae, Ginglymostomatidae, Hemiscylliidae, Orectolobidae, Parascylliidae, Rhynchodontidae, Stegostomatidae. - Order Pristiophorifirmes - Family: Pristiophoridae. - Order Squatiniformes - Family: Squatinidae. In Contributions to the study of the comparative morphology of teeth and other relevant ichthyodorulites in living supra-specific taxa of Chondrichthyan fishes, ed. M. Stehmann. Bulletin de l'Institut Royal des Sciences Naturelles de Belgique, Biologie 62: 193-254.

Herman, J., M. Hovestadt-Euler, D.C. Hovestadt, and M. Stehmann. 1994. Part B: Batomorphii No. 1a: Order Rajiformes - Suborder Rajoidei - Family: Rajidae Genera and Subgenera: Anacanthobatis (Schroederobatis), Anacanthobatis (Springeria), Breviraja, Dactylobatus, Gurgesiella (Gurgesiella), Gurgesiella (Fenestraja), Malacoraja, Neoraja and Pavoraja. In Contributions to the study of the comparative morphology of teeth and other relevant ichthyodorulites in living supra-specific taxa of Chondrichthyan fishes, ed. M. Stehmann. Bulletin de l'Institut Royal des Sciences Naturelles de Belgique, Biologie 64: 165-207.

Herman, J., M. Hovestadt-Euler, D.C. Hovestadt, and M. Stehmann. 1995. Part B: Batomorphii No. 1b: Order Rajiformes - Suborder Rajoidei - Family: Rajidae - Genera and Subgenera: Bathyraja (with a deep-water, shallow-water and transitional morphotype), Psammobatis, Raja (Amblyraja), Raja (Dipturus), Raja (Leucoraja), Raja (Raja), Raja (Rajella) (with two morphotypes), Raja (Rioraja), Raja (Rostroraja), Raja lintea, and Sympterygia. In Contributions to the study of the comparative morphology of teeth and other relevant ichthyodorulites in living supra-specific taxa of Chondrichthyan fishes, ed. M. Stehmann. Bulletin de l'Institut Royal des Sciences Naturelles de Belgique, Biologie 65: 237-307.

Herman, J., M. Hovestadt-Euler, D.C. Hovestadt, and M. Stehmann. 1996. Part B: Batomorphii No. 1c: Order Rajiformes - Suborder Rajoidei - Family: Rajidae - Genera and Subgenera: Arhynchobatis, Bathyraja richardsoni-type, Cruriraja, Irolita, Notoraja, Pavoraja (Insentiraja), Pavoraja (Pavoraja), Pseudoraja, Raja (Atlantoraja), Raja (Okamejei) and Rhinoraja. In Contributions to the study of the comparative morphology of teeth and other relevant ichthyodorulites in living supra-specific taxa of Chondrichthyan fishes, ed. M. Stehmann. Bulletin de l'Institut Royal des Sciences Naturelles de Belgique, Biologie 66: 179-236.

Huxley, T.H. 1880. On the application of the laws of evolution to the arrangement of the Vertebrata, and more particularly of the Mammalia. Proceedings of the Zoological Society of London 43: 649-662.

ICZN [International Commission on Zoological Nomenclature]. 1999. International Code of Zoological Nomenclature, 4th ed. London: International Trust for Zoological Nomenclature.

Iglésias, S.P., L. Toulhoat, and D.Y. Sellos. 2010. Taxonomic confusion and market mislabelling of threatened skates: important consequences for their conservation status. Aquatic Conservation: Marine and Freshwater Ecosystems 20(3): 319-333. https://doi. org/10.1002/aqc. 1083 .

Jonet, S. 1968. Notes d'ichthyologie miocène portugaise. V. - Quelques batoïdes. Revista da Faculdade de Ciências da Universidade de Lisboa 15: 233-258.

Kajiura, S.M., and T.C. Tricas. 1996. Seasonal dynamics of dental sexual dimorphism in the Atlantic stingray Dasyatis sabina. Journal of Experimental Biology 199(10): 2297-2306.

Last, P.R., W.T. White, M.R. Carvalho, B. Séret, M.F.W. Stehmann, and G.J.P. Naylor, eds. 2016. Rays of the world. Clayton South: CSIRO Publishing.

Lawley, R. 1876. Nuovi studi sopra ai pesci ed altri vertebrati fossili delle colline Toscane. Florence: Tipografia dell'Arte della Stampa.

Lea, J.S.E., R. Daly, C. Leon, C.A.K. Daly, and C.R. Clarke. 2019. Life after death: behaviour of multiple shark species scavenging a whale carcass. Marine and Freshwater Research 70(2): 302-306. https://doi.org/10.1071/MF18157.
Manganelli, G., and V. Spadini. 2003. Gli squali del Pliocene Senese. Siena: Cantagalli.

Manganelli, G., A. Benocci, and V. Spadini. 2006. The scientific bibliography of Roberto Lawley (1818-1881) and his contribution to the study of fossil sharks. Archives of Natural History 33(2): 267-281. https://doi.org/10.3366/anh.2006.33.2.267.

Manzi, V., R. Gennari, F. Hilgen, W. Krijgsman, S. Lugli, M. Roveri, and F.J. Sierro. 2013. Age refinement of the Messinian salinity crisis onset in the Mediterranean. Terra Nova 25(4): 315-322. https://doi.org/10.1111/ter.12038.

Marramà, G., O. Schultz, and J. Kriwet. 2019. A new Miocene skate from the central Paratethys (Upper Austria): the first unambiguous skeletal record for the Rajiformes (Chondrichthyes: Batomorphii). Journal of Systematic Palaeontology 17(11): 937-960. https://doi. org/10.1080/14772019.2018.1486336.

Matott, M.P., P.J. Motta, and R.E. Hueter. 2005. Modulation in feeding kinematics and motor pattern of the nurse shark Ginglymostoma cirratum. Environmental Biology of Fishes 74: 163-174. https:// doi.org/10.1007/s10641-005-7435-3.

McCourt, R.M., and A.N. Kerstitch. 1980. Mating behavior and sexual dimorphism in dentition in the stingray Urolophus concentricus from the Gulf of California. Copeia 1980(4): 900-901.

McEachran, J.D., and K.A. Dunn. 1998. Phylogenetic analysis of skates, a morphologically conservative clade of elasmobranchs (Chondrichthyes: Rajidae). Copeia 1998(2): 271-290.

Merella, M., A. Collareta, S. Casati, A. Di Cencio, W. Landini, and G. Bianucci. 2020. The lower Pliocene elasmobranch assemblage from Arcille (Campagnatico, Grosseto Province): palaeoecological and palaeoenvironmental significance. Fossilia 2020: 41-43. https://doi.org/10.32774/FosRepPal.2020.0611.

Monegatti, P., and S. Raffi. 2001. Taxonomic diversity and stratigraphic distribution of Mediterranean Pliocene bivalves. Palaeogeography, Palaeoclimatology, Palaeoecology 165(3-4): 171-193. https ://doi.org/10.1016/S0031-0182(00)00159-0.

Motta, P.J., R.E. Hueter, T.C. Tricas, and A.P. Summers. 2002. Kinematic analysis of suction feeding in the nurse shark, Ginglymostoma cirratum (Orectolobiformes, Ginglymostomatidae). Copeia 2002(1): 24-38. https://doi.org/10.1643/00458511(2002)002[0024:KAOSFI]2.0.CO;2.

Naylor, G.J.P., J.N. Caira, K. Jensen, K.A.M. Rosana, N. Straube, and C. Lakner. 2012a. Elasmobranch phylogeny: a mitochondrial estimate based on 595 species. In Biology of sharks and their relatives, 2nd ed., eds. J.C. Carrier, J.A. Musick, and M.R. Heithaus, 31-56. Boca Raton: CRC Press. https://doi.org/10.1201/B1186 7-9.

Naylor, G.J.P., J.N. Caira, K. Jensen, K.A.M. Rosana, W.T. White, and P.R. Last. 2012b. A DNA sequence-based approach to the identification of shark and ray species and its implications for global elasmobranch diversity and parasitology. Bulletin of the American Museum of Natural History 367: 1-262.

Nelson, J.S. 1994. Fishes of the world, 3rd ed. New York: John Wiley \& Sons.

Notarbartolo di Sciara, G., and I. Bianchi. 1998. Guida degli squali e delle razze del Mediterraneo. Padua: Franco Muzzio.

Pascucci, V., A. Costantini, I.P. Martini, and R. Dringoli. 2006. Tectono-sedimentary analysis of a complex, extensional, Neogene basin formed on thrust-faulted, Northern Apennines hinterland: Radicofani Basin, Italy. Sedimentary Geology 183(1-2): 71-97. https://doi.org/10.1016/j.sedgeo.2005.09.009.

Pertusati, P.C., G. Plesi, and A. Cerrina Feroni. 1980. Un episodio di raccorciamento interposto tra fasi di distensione nel calcare di Rosignano (neoautoctono) del bacino della Fine (Toscana meridionale). Bollettino della Società Geologica Italiana 99: 175-181.

Pimiento, C., J.N. Griffin, C.F. Clements, D. Silvestro, S. Varela, M.D. Uhen, and C. Jaramillo. 2017. The Pliocene marine megafauna extinction and its impact on functional diversity. Nature 
Ecology \& Evolution 1: 1100-1106. https://doi.org/10.1038/s4155 9-017-0223-6.

Prista, G.A., R.J. Agostinho, and M.A. Cachão. 2015. Observing the past to better understand the future: a synthesis of the Neogene climate in Europe and its perspectives on present climate change. Open Geosciences 7: 65-83. https://doi.org/10.1515/ geo-2015-0007.

Quignard, J.P., and J.A. Tomasini. 2000. Mediterranean fish biodiversity. Biologia Marina Mediterranea 7(3): 1-66.

Raffi, S., and P. Monegatti. 1993. Bivalve taxonomic diversity throughout the Italian Pliocene as a tool for climatic-oceanographic and stratigraphic inferences. Ciências da Terra (UNL) 12: 45-50.

Ragaini, L., F. Ficini, G. Zanchetta, E. Regattieri, N. Perchiazzi, and L. Dallai. 2019. Mineralogy and oxygen isotope profile of Pelecyora gigas (Veneridae, Bivalvia) from Tuscan Pliocene. Alpine and Mediterranean Quaternary 32(1): 5-13. https://doi.org/10.26382 /AMQ.2019.01.

Ramírez-Amaro, S., F. Ordines, A. Picornell, J.A. Castro, C. Ramon, E. Massutí, and B. Terrasa. 2018. The evolutionary history of Mediterranean Batoidea (Chondrichthyes: Neoselachii). Zoologica Scripta 47(6): 686-698. https://doi.org/10.1111/zsc.12315.

Rio, D., I. Raffi, and G. Villa. 1990. Pliocene-Pleistocene calcareous nannofossil distribution patterns in the Western Mediterranean. In Proceedings of the Ocean Drilling Program, Scientific Results 107, eds. K..A. Kastens, J. Mascle, et al.: 513-533. https://doi. org/10.2973/odp.proc.sr.107.164.1990.

Serena, F. 2005. Field identification guide to the sharks and rays of the Mediterranean and Black Sea. In FAO species identification guide for fishery purposes. Rome: FAO.

Serena, F., C. Mancusi, and M. Barone. 2010. Field identification guide to the skates (Rajidae) of the Mediterranean Sea. Guidelines for data collection and analysis. Biologia Marina Mediterranea 17 (Supplement 2): 1-204.

Sorbi, S., D.P. Domning, S.C. Vaiani, and G. Bianucci. 2012. Metaxytherium subapenninum (Bruno, 1839) (Mammalia, Dugongidae), the latest sirenian of the Mediterranean Basin. Journal of Vertebrate Paleontology 32(3): 686-707. https://doi.org/10.1080/02724 634.2012.659100.

Sousa Rangel, B. de, S.S. Rodrigues, P.O, Favaron, A.F. Amorim, and R.E.G. Rici. 2014. Structure and dental sexual dimorphism in Dasyatis hypostigma (Santos \& Carvalho, 2004) (Myliobatiformes, Dasyadae). In Microscopy: advances in scientific research and education. Microscopy book series-2014 edition, ed. A. Méndez-Vilas, 89-94. Badajoz: FORMATEX.

Sousa Rangel, B. de, J. Santander-Neto, R.E.G. Rici, and R. Lessa. 2016. Dental sexual dimorphism and morphology of Urotrygon microphthalmum. Zoomorphology 135: 367-374. https://doi. org/10.1007/s00435-016-0312-0.

Stumpf, S., and J. Kriwet. 2019. A new Pliensbachian elasmobranch (Vertebrata, Chondrichthyes) assemblage from Europe, and its contribution to the understanding of late Early Jurassic elasmobranch diversity and distributional patterns. PalZ. Paläontologische Zeitschrift 93: 637-658. https://doi.org/10.1007/s1254 2-019-00451-4.

Tinelli, C. 2013. Marine vertebrates from Pliocene shell beds from Tuscany (Italy): prospecting, taphonomy, palaeoecology and systematic palaeontology. $\mathrm{PhD}$ dissertation, Università di Pisa, Italy.

Tinelli, C., A. Ribolini, G. Bianucci, M. Bini, and W. Landini. 2012. Ground penetrating radar and palaeontology: the detection of sirenian fossil bones under a sunflower field in Tuscany (Italy). Comptes Rendus Palevol 11(6): 445-454. https://doi. org/10.1016/j.crpv.2012.04.002.

Vai, G.B. 1989. A fied trip guide to the Romagna Apennine geology. The Lamone Valley. Bollettino della Società Paleontologica Italiana 28: 343-367.

Valsecchi, E., P. Pasolini, M. Bertozzi, F. Garoia, N. Ungaro, M. Vacchi, B. Sabelli, and F. Tinti. 2005. Rapid Miocene-Pliocene dispersal and evolution of Mediterranean rajid fauna as inferred by mitochondrial gene variation. Journal of Evolutionary Biology 18(2): 436-446. https://doi.org/10.1111/j.1420-9101.2004.00829 .x.

Violanti, D. 2012. Pliocene Mediterranean foraminiferal biostratigraphy: a synthesis and application to the paleoenvironmental evolution of Northwestern Italy. In Stratigraphic analysis of layered deposits, ed. Ö. Elitok, 123-160. London: Intech Open. https:// doi.org/10.5772/35103.

Vullo, R., H. Cappetta, and D. Néraudeau. 2007. New sharks and rays from the Cenomanian and Turonian of Charentes, France. Acta Palaeontologica Polonica 52(1): 99-116.

Weigmann, S. 2016. Annotated checklist of the living sharks, batoids and chimaeras (Chondrichthyes) of the world, with a focus on biogeographical diversity. Journal of Fish Biology 88(3): 837-1037. https://doi.org/10.1111/jfb.12874. 